\title{
Distance traveled by mice after envenomation by a rattlesnake (C. viridis)
}

\author{
KAREN ESTEP, THOMAS POOLE, CHARLES W. RADCLIFFE, \\ BARBARA O'CONNELL, and DAVID CHISZAR \\ University of Colorado, Boulder, Colorado 80309, and \\ Denver Zoological Gardens, Denver, Colorado 80205
}

\begin{abstract}
Adult mice (Mus musculus, C3H) envenomated by adult prairie rattlesnakes (Crotalus viridis) traveled an average of $185.6 \mathrm{~cm}$ in an open field prior to becoming immobilized $(78 \mathrm{sec})$. The range of distances traveled by the 20 envenomated mice in this study was $0-676.5 \mathrm{~cm}$. These distances give an indication of the extent of the trailing task that confronts a prairie rattlesnake under natural conditions. Hence, laboratory studies of trailing behavior in rattlesnakes should use trails of at least $180-200 \mathrm{~cm}$ if results are to have ecological validity. Of course, data from additional strains of rodents envenomated by additional species of rattlesnakes should be accumulated in order to supplement the information provided here.
\end{abstract}

Rattlesnakes typically strike and release adult rodent prey (Gans, 1966; Radcliffe, Chiszar, \& O'Connell, 1980), permitting the envenomated animals to wander freely while the venom takes effect. Releasing such prey is considered to be an adaptation that spares the snake from damage resulting from rodent teeth and claws. However, the snake must then locate its dead prey, which may have wandered a considerable distance. This task is accomplished by a profound change in snake chemosensitivity consequent to striking (Chiszar, Radcliffe, \& Scudder, 1977; Chiszar, Radcliffe, \& Smith, 1978; Gillingham \& Clark, 1981). A predatory strike results in a sustained, high rate of tongue flicking, by which molecules are transferred from the environment to the vomeronasal organs (for reviews, see Burghardt, 1970, 1980; Chiszar \& Scudder, 1980). Strike-induced chemosensory searching brings the snake into contact with the envenomated rodent's trail and allows the snake to follow it with precision (Dullemeijer, 1961; Naulleau, 1964; Golan, Radcliffe, Miller, O'Connell, \& Chiszar, Note 1).

Since all studies of this trailing phenomenon have been conducted in laboratory cages and since trail lengths have been circumscribed by the artificial boundaries imposed by experimental procedures and/or captive enviroments, it is important to determine the distance that a mouse could travel under less restricted conditions. Such data will reveal (1) the extent of the trailing task that would confront the snake under natural conditions and (2) the extent to which experimental procedures in common use (Kubie \& Halpern, 1979; Golan et al., Note 1) are adequate models of the natural

H. P. Alpern and the Institute for Behavior Genetics kindly provided mice for these experiments. Reprint requests should be sent to D. Chiszar, Department of Psychology, University of Colorado, Boulder, Colorado 80309. situation. The present study was designed to provide this information.

\section{METHOD}

Subjects

Six adult prairie rattlesnakes (Crotalus viridis; mean length = $78 \mathrm{~cm}$ ) were used as venom donors. Snakes were individually maintained in glass cages $(62 \times 32 \times 32 \mathrm{~cm})$ and had been in captivity for at least 2 years. They had been accepting rodent prey (Mus musculus; mean weight $=20 \mathrm{~g}$ ) on a weekly schedule during this entire period. Laboratory temperature was $26^{\circ} \mathrm{C} \pm 1^{\circ} \mathrm{C}$ during photophase $(0700-1900)$ and $23^{\circ} \mathrm{C} \pm 1^{\circ} \mathrm{C}$ during scotophase.

Forty mice (Mus musculus, $\mathrm{C} 3 \mathrm{H} ; 20-24 \mathrm{~g}$ ) were selected from a colony maintained by the psychology department and randomly assigned to two groups $(n=20)$, with the restriction that each group contain 10 males and 10 females.

\section{Procedure}

All mice were observed in an open field for $5 \mathrm{~min}(20$ successive 15 -sec periods). The apparatus had inside dimensions of $100 \times 100 \times 90 \mathrm{~cm}$, and the floor was marked into $3616.5-\mathrm{cm}$ squares. Mice in one group (controls) were removed from their home cages via forceps applied to the tail. While suspended from the forceps, the mouse was lowered into a rattlesnake cage but held out of striking range for 3 sec. The mouse was immediately withdrawn and placed into the open field. Experimental mice were treated exactly like the controls, except that the snake was allowed to strike the mouse at the end of the 3-sec presentation. Less than $3 \mathrm{sec}$ was required to transfer the mouse to the nearby open field. The following measures of open-field performance were taken: (1) number of squares traversed during each 15 -sec period, (2) latency (in seconds) for experimental mice to become immobile, and (3) latency for experimental mice to die (defined as cessation of respiration).

Each rattlesnake struck one experimental mouse per week. Hence, four weeks were required to gather all the data. The open field was cleaned after each trial.

\section{RESULTS}

Table 1 presents descriptive statistics that indicate that male and female experimental mice did not differ 
Table 1

Means and Standard Deviations for Each of the Dependent Variables Recorded in This Study

\begin{tabular}{|c|c|c|c|c|c|c|c|c|c|c|c|}
\hline & & \multirow{2}{*}{\multicolumn{2}{|c|}{$\begin{array}{l}\text { Body Weight } \\
\text { (in Grams) }\end{array}$}} & \multicolumn{4}{|c|}{ Latency (in Seconds) } & \multicolumn{4}{|c|}{ Distance Traveled } \\
\hline & & & & To Imm & lization & & & Number & Squares & In Cen & neters \\
\hline \multicolumn{2}{|l|}{ Group } & Mean & SD & Mean & SD & Mean & SD & Mean & SD & Mean & SD \\
\hline Experimental & $\begin{array}{l}\text { Male } \\
\text { Female }\end{array}$ & $\begin{array}{l}21.8 \\
21.7\end{array}$ & $\begin{array}{l}1.4 \\
1.1\end{array}$ & $\begin{array}{r}54.7 \\
101.4\end{array}$ & $\begin{array}{r}36.7 \\
151.6\end{array}$ & $\begin{array}{l}240.1 \\
209.8\end{array}$ & $\begin{array}{l}218.7 \\
200.7\end{array}$ & $\begin{array}{r}14.6 \\
7.9\end{array}$ & $\begin{array}{r}13.8 \\
8.0\end{array}$ & $\begin{array}{l}240.9 \\
130.3\end{array}$ & $\begin{array}{l}227.7 \\
133.4\end{array}$ \\
\hline Control & $\begin{array}{l}\text { Male } \\
\text { Female }\end{array}$ & $\begin{array}{l}21.9 \\
21.5\end{array}$ & $\begin{array}{l}1.3 \\
1.3\end{array}$ & & & & & $\begin{array}{l}163.8 \\
146.8\end{array}$ & $\begin{array}{r}105.0 \\
80.1\end{array}$ & $\begin{array}{l}2702.7 \\
2422.2\end{array}$ & $\begin{array}{l}1732.8 \\
1323.1\end{array}$ \\
\hline
\end{tabular}

Note-Distance measures were pooled across 15 -sec periods. See Figure 1 and Table 2 for unpooled means and corresponding inferential statistics.

significantly in body weight, latency to become immobile, or latency to die. It is noteworthy that latency to die was significantly longer than latency to become immobile $[\mathrm{t}(19)=4.14, \mathrm{p}<.01]$, indicating that venom inhibits movement long before it causes death. Although both effects may be derived from the same physiological consequences of venom, this is not necessarily the case, and it is reasonable to hypothesize that strong selective pressures have produced venom components that rapidly inhibit rodent movement whether or not they also contribute to the rodent's death. Yet, the fact that the two latency measures were correlated $[r(18)=.65, p<.01]$ is suggestive of some common mediation. Of course, nonenvenomated mice traveled farther during the 5-min test than envenomated mice $[F(1,36)=46.84, p<.01$; see Table 1 , Columns 4 and
5, Figure 1, and Table 2]. Envenomated males traveled farther than envenomated females, even though males became immobilized numerically sooner than females. However, this is simply a reflection of the fact that males generally exhibited more (and faster) locomotion in the open field than did females, and this main effect of sex was visible even during the first $15 \sec [F(1,36)=$ $7.36, \mathrm{p}<.05]$. The potential interaction involving envenomation vs. nonenvenomation and sex was not significant at any point shown along the abscissa of Figure 1 (all Fs $\leqslant 1.0$ ). Therefore, it is concluded that males and females differed slightly in rate of ambulation, but not in the present measures of susceptibility to envenomation. Both sexes revealed significant effects of envenomation during the third 15 -sec period in the open field (Table 2).

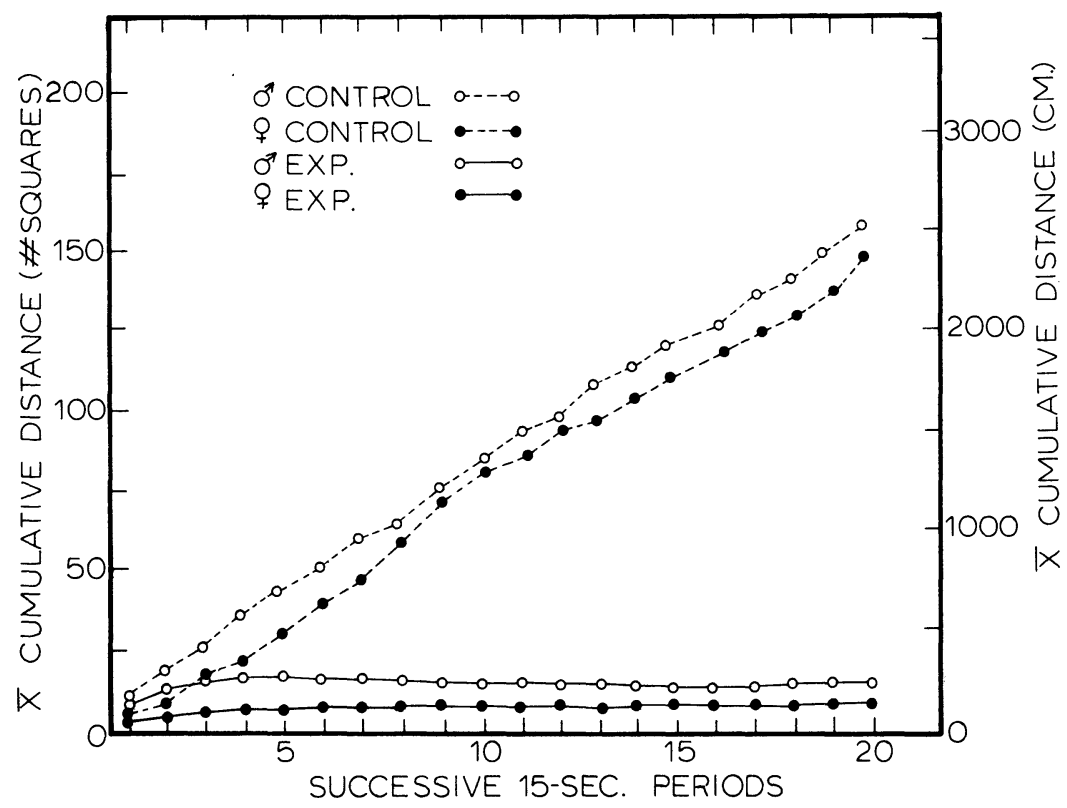

Figure 1. Mean cumulative distance traveled by male and female mice in each group. Cumulative distance is shown for each successive 15 -sec period. Left ordinate shows number of squares traversed in the open field; right ordinate expresses the distance in centimeters. 
Table 2

Results of 2 by 2 ANOV As Applied to Selected 15-Sec Periods Shown in Figure 1

\begin{tabular}{|c|c|c|c|c|c|c|c|c|}
\hline & \multicolumn{8}{|c|}{ Selected 15-Sec Periods } \\
\hline & 1 & 2 & 3 & 4 & 5 & 6 & 10 & 20 \\
\hline & \multicolumn{8}{|c|}{ F Ratios $(\mathrm{df}=1,36)$} \\
\hline $\begin{array}{l}\text { Sex } \\
\text { Envenomation } \\
\text { Interaction }\end{array}$ & $\begin{array}{c}7.36^{*} \\
.81 \\
.27\end{array}$ & $\begin{array}{l}8.55 \dagger \\
3.99 \\
.04\end{array}$ & $\begin{array}{c}5.09^{*} \\
7.15^{*} \\
.08\end{array}$ & $\begin{array}{c}4.18^{*} \\
12.77 \dagger \\
.24\end{array}$ & $\begin{array}{c}2.80 \\
16.43 \dagger \\
.25\end{array}$ & $\begin{array}{c}1.86 \\
18.25 \dagger \\
.20\end{array}$ & $\begin{array}{c}.62 \\
28.94 \dagger \\
.05\end{array}$ & $\begin{array}{c}.31 \\
46.84 \dagger \\
.05\end{array}$ \\
\hline & \multicolumn{8}{|c|}{ Percent of Variance } \\
\hline $\begin{array}{l}\text { Sex } \\
\text { Envenomation } \\
\text { Interaction }\end{array}$ & $\begin{array}{r}16.53 \\
1.83 \\
.62\end{array}$ & $\begin{array}{r}17.60 \\
8.21 \\
.09\end{array}$ & $\begin{array}{r}10.53 \\
14.81 \\
.16\end{array}$ & $\begin{array}{r}7.87 \\
24.01 \\
.46\end{array}$ & $\begin{array}{r}5.05 \\
29.60 \\
.46\end{array}$ & $\begin{array}{r}3.30 \\
32.41 \\
.36\end{array}$ & $\begin{array}{r}.95 \\
44.10 \\
.08\end{array}$ & $\begin{array}{r}.38 \\
56.28 \\
.07\end{array}$ \\
\hline Percent of Envenomated Mice Immobilized & 25.00 & 40.00 & 45.00 & 50.00 & 60.00 & 80.00 & 90.00 & 95.00 \\
\hline Total $\mathbf{S}^{2}$ & 20.10 & 97.90 & 203.70 & 383.40 & 619.60 & 895.60 & 2652.80 & 9452.10 \\
\hline
\end{tabular}

$* p<.05 . \quad t p<.01$.

\section{DISCUSSION}

The most important finding of this investigation was that envenomated mice traveled an average of $185.6 \mathrm{~cm}$ prior to becoming immobilized. These procedures probably underestimated the maximal distance such mice could travel because of the 2 or $3 \mathrm{sec}$ that were required to transport the mice from the snake cage to the open field. If appropriate adjustments are made in the experimental data, the mean becomes about $200 \mathrm{~cm}$. Hence, procedures for analyzing rattlesnake trailing behavior should use trails of this length if results are to have ecological validity. However, studies such as the one reported here should be repeated with additional strains of mice, as well as additional species of rattlesnakes. It is quite likely that significant variability will derive from both of these factors.

The variability of the present data was considerable. The range of distance traveled by envenomated mice was from $0 \mathrm{~cm}$ to $676.5 \mathrm{~cm}$. Perhaps the higher value gives an indication of the upper limit of rattlesnake trailing ability. If so, experimental trails of $180-200 \mathrm{~cm}$ do not represent challenging situations for these predators.

Rattlesnakes typically do not begin to search for rodent prey until 3 or $4 \mathrm{~min}$ after the predatory strike (Chiszar et al., 1977). Since this period coincides with the mean latency to die (Table 1), it can be hypothesized that rattlesnakes have experienced selective pressures against locating the wounded prey while it is still capable of defensive actions.

\section{REFERENCE NOTE}

1. Golan, L., Radcliffe, C. W., Miller, T., O’Connell, B., \& Chiszar, D. Prey trailing by the prairie rattlesnake (Crotalus v. viridis). Manuscript under review, 1981.

\section{REFERENCES}

Burghardt, G. M. Chemical perception in reptiles. In J. W. Johnston, D. G. Moulton, \& A. Turk (Eds.), Communication by chemical signals. New York: Appleton-Century-Crofts, 1970.

BURGHARDT, G. M. Behavioral and stimulus correlates of vomeronasal functioning in reptiles: Feeding, grouping, sex, and tongue use. In D. Müller-Schwarze \& R. M. Silverstein (Eds.), Chemical signals: Vertebrates and aquatic invertebrates. New York: Plenum, 1980.

Chiszar, D., Radcliffe, C. W., \& Scudder, K. M. Analysis of the behavioral sequence emitted by rattlesnakes during feeding episodes. I. Striking and chemosensory searching. Behavioral Biology, 1977, 21, 418-425.

Chiszar, D., Radcliffe, C. W., \& Smith, H. M. Chemosensory searching for wounded prey by rattlesnakes is released by striking: A replication report. Herpetological Review, 1978, 9, 54-56.

Chiszar, D., \& Scudder, K. M. Chemosensory searching by rattlesnakes during predatory episodes. In D. Müller-Schwarze \& R. M. Silverstein (Eds.), Chemical signals: Vertebrates and aquatic invertebrates. New York: Plenum, 1980.

Dullemeijer, P. Some remarks on the feeding behavior of rattlesnakes. Koninklijke Nederlandische Academie van Wetenschappen (Series C), 1961, 64, 383-396.

GaNs, C. The biting behavior of solenoglyph snakes-Its bearing on the pattern of envenomation. In Proceedings of the International Symposium on Venomous Animals. Sao Paulo, Brazil: Instituto Butantan, 1966.

Gillingham, J. C., \& Clark, D. L. An analysis of prey searching behavior in the western diamondback rattlesnake, Crotalus atrox. Behavioral and Neural Biology, 1981, 32, 235-240.

Kubie, J. L., \& HAlPern, M. The chemical senses involved in garter snake prey trailing. Journal of Comparative and Physiological Psychology, 1979, 93, 648-667.

Naulleau, G. Premieres observations sur le compartement de chasse et de capture chez les vipers et les couleuvres. La Terre et la Vie, 1964, 1, 54-76.

Radcliffe, C. W., Chiszar, D., \& O'Connell, B. Effects of prey size on poststrike behavior in rattlesnakes (Crotalus durissus, C. enyo, and C. viridis). Bulletin of the Psychonomic Society, $1980,16,449-450$.

(Received for publication June 23; 1981.) 